\title{
ASSOCIATION BETWEEN MATERNAL NUTRITION AWARENESS AND THE RISK OF STUNTING AMONG CHILDREN UNDER FIVE IN TAPANULI, NORTH SUMATERA
}

\author{
Meiyati Simatupang, Herlina,Rumiris Simatupang, Ronald Sagala
}

School of Health Sciences Nauli Husada Sibolga

\begin{abstract}
Background: Stunting is defined as height-for-age z-score (HAZ) of less than -2 standard deviation (SD) below the median of a reference standard. Stunting not only affects a child's health, making them more susceptible to disease and infection, but also impairs their mental and physical development, meaning children who suffer from stunting are less likely to achieve their full height and cognitive potentials as adults. Stunting is caused by long-term insufficient nutrient intake and/or frequent infections. This study aimed to examine the association between nutrition awareness and the risk of stunting among children under five in Tapanuli, North Sumatera

Subjects and Method: This was a descriptive and analytic study. A total of 109 children aged 6-6o months was selected for this study. The dependent variable was the risk of stunting. The independent variable was maternal nutrition awareness. Data on stunting were obtained from the health and nutrition record. The other data were collected using questionnaire. The data were analyzed by cross tabulation.

Results: A total of 71 out of 109 mothers (65.1\%) had good nutritional awareness. A total of 106 out of 109 children (97.2\%) did not experience stunting. Good maternal nutritional awareness was associated with less risk of stunting, and it was statistically significant.

Conclusion: Good maternal nutritional awareness is associated with less risk of stunting.
\end{abstract}

Keywords: maternal, nutritional awareness, children under five, stunting

Correspondence:

Meiyati Simatupang. School of Health Sciences Nauli Husada Sibolga, North Sumatera. Email: Meiyatisimatupang.sbg65@gmail.com. Mobile: 081370320730.

The 5th International Conference on Public Health Best Western Premier Hotel, Solo, Indonesia, February 13-14, 2019 | 276 https://doi.org/10.26911/theicph.2019.03.28 